\title{
VIRTUDES ROMANAS E VALORES CRISTÃOS: um estudo acerca da Ética e da Política na Antigüidade Tardia
}

SINTESE - No decorrer do IV século d. C. o mundo tardo antigo romano vivencia uma série de profundas transformaçōes que alteram fundamentalmente as estruturas sociais, econômicas, políticas, religiosas e mentais clássicas fazendo surgir outras que resistimos a chamar de medievais. Dentre essas mudanças uma nos apresenta como tendo uma particular relevância e interesse, qual seja, a expansão da religião cristä no âmbito da bacia do mar Mediterrâneo, isto é, observamos um lento, mas constante processo de cristianização da sociedade tardo antiga romana. Nosso trabalho tem por objetivo abordar um aspecto deste fenômeno, a saber o diálogo, o encontro e a mútua influência entre a doutrina cristã e a tradiçăo cultural romano-helenistica, através da análise do processo de transformaçōes das idéias morais e politicas dos romanos em valores e virtudes cristãs.
ABSTRACT - Along the 4th century a.C. the later old Roman world lives a series of deep changes that alter the classical social structures, economic, political, religious and mental, bringing into light others we resist to call medieval. Among these changes, one of all is to us particular, that is, the expansion of Christian religion in the range of Mediterranean Sea bay, $i$. e., we observe a slow but constant process of christianization of the later ancient Roman society. Our work has the aim of focussing one aspect of this phenomenon: to know the dialogue, the meeting and mutual influence between the Christian doctrine and the cultural roman-greek tradition through the analysis of the changing process of moral and political ideas of Romans in values and Christian virtues.

No decorrer do IV século o mundo tardo antigo romano vivencia um conjunto de profundas e importantes transformações que modificam substancialmente as estruturas sociais, econômicas, políticas, religiosas e mentais clássicas, fazendo surgir outras que resistimos a chamar de medievais ${ }^{1}$ e que caracterizam o momento histórico que denominamos de Antigüidade Tardia. ${ }^{2}$

- Universidade Federal do Espírito Santo - UFES - Vitória.

1 TEJA, R. "Monacato e historia social: los origenes del monacato y la sociedad del Bajo Imperio Romano". IN HIDALGO DE LA VEGA, M.J. (ed). La historia en el contexto de las ciencias humanas y sociales. Salamanca: Universidad de Salamanca, 1989. p. 81.

2 Acerca da discussão sobre a Antigüidade tardia ver especialmente BROWN, P. Genèse de l'Antiquité Tardive. Paris: Gallimard,1984. MARROU, H. I. Decadencia Romana o Antiguedad Tardia. Madrid: Rialp, 1980. MAEIR, F. G. Las transformaciones del mundo mediterraneo. Siglo III-VIII. Madrid: Siglo XXI, 1972.

\begin{tabular}{|l|l|l|l|l|l|}
\hline VERITAS & Porto Alegre & v. 40 & $\mathrm{n}^{2} 159$ & Setembro 1995 & p. $319-335$ \\
\hline
\end{tabular}


Dentro dessas mudanças, as transformações ocorridas na religiosidade e no universo mental dos homens do mundo tardo antigo apresentam uma importância crucial, pois elas são elementos decisivos para a compreensão do fenônemo fundamental que marca a sociedade da Antigüidade Tardia: a expansão da religião cristã no âmbito da bacia do mar Mediterrâneo, em outras palavras, o processo de cristianização que atinge toda a estrutura social do Baixo Império Romano.

A abordagem historiográfica do processo de cristianização do mundo tardo romano tem privilegiado dois enfoques principais. Por um lado, o problema é compreendido através de sua ligação com a conversão dos imperadores. Por outro, como o resultado da atuação de mecanismos estatais para a imposição da religião cristä. Em sintese, os dois enfoques se integram numa perspectiva de análise que prioriza a existência de uma política religiosa estatal de favorecimento ao cristianismo. ${ }^{3}$

Esta perspectiva de análise, apesar de abordar questöes fulcrais no processo de cristianização da sociedade tardo antiga romana, tais como a importância da conversão dos imperadores e a política estatal de favorecimento à Igreja, não consegue responder a todas as perguntas colocadas por este complexo fenônemo.

É preciso, portanto, buscar novas perspectivas de análise, novas hipóteses que permitam compreender o processo de cristianização da sociedade tardo antiga por. ângulos ainda não explorados. A abordagem proposta por Peter $\mathrm{Brown}^{4}$ que privilegia os mecanismos de difusão da doutrina cristã no seio dos diferentes grupos sociais que compunham a estrutura social do Baixo Império, apresenta-se como uma nova linha de pesquisa bastante fecunda para entender o fenômeno da cristianização.

Nossa perspectiva de análise parte da proposta de.abordagem feita por Peter Brown acerca dos mecanismos internos de expansão da doutrina cristã no seio da sociedade tardo antiga, mas apresenta algumas características próprias. Isto é, perceber e compreender o processo de conversão na Antigüidade Tardia através da construção de um discurso evangelizador, realizado por uma inteligência cristã, capaz de unir a tradição cultural e os vialores romanos com a doutrina cristã.

Dentro desta perspectiva de abordagem do problema, escolhemos a aristocracia da cidade de Roma como o grupo social a ser analisado. Tal escolha explica-se e justifica-se fundamentalmente por ser este grupo o guardião e o mantenedor das tradições romanas, ou pelo menos os seus membros assim se consideravam.

André Chastagnol define a aristocracia de Roma no IV século como um grupo de familias senatoriais, cujas raizes remontam, muitas vezes, à época republicana. ${ }^{5}$ É um grupo que neste momento mantém intacto seu prestígio moral, encarnado no

3 Podemos citar como exemplo desta abordagem obras clássicas e importantes como FLICHE, A. e MARTIN, V. Histoire de l'Eglise. Paris: Bloud et Gay, 1934. vol. III. BARDY, G. L'Eglise et les derniers romains. Paris: Robert Laffont, 1948. LABRIOLLE, P. La reation païenne: Paris: L'Artisan du Livre, 1948.

4 BROWN, P. "Aspects of christianization of the Roman Aristocracy". IN Joumal of roman Studies. $\mathrm{n}^{\circ}$ 51, 1961. p. 1-11. Neste artigo o autor apenas propõe esta abordagem, mas não chega a desenvolvêla.

CHASTAGNOL, A. Le Senat Romain à l'époque imperiale. Paris: Les Belles lettres, 1992. p. 302. 
mos maionum, na idéia de Roma e da civilização universal, proclamando-se herdeiro da herança cultural romano-helenística. ${ }^{6}$

As referências de Símaco, em suas cartas, acerca da aristocracia de Roma, demonstram claramente como os membios deste grupo social consideravam a si próprios: "A melhor parte do gênero humano. Um sangue nobre que se reconhece sempre. Os homens mais nobres do gênero humano".?

O nosso problema é entender o processo de cristianização no seio deste grupo social que se constitui como um dos últimos bastiões do paganismo ao longo do IV século.

Como afirmamos acima, nossa resposta a esta questão privilegia os mecanismos internos de expansão da doutrina cristã nos diversos grupos que compõem a sociedade tardo antiga, sem esquecer ou menosprezar, no entanto, a política de favorecimento estatal à Igreja.

Dentre esses mecanismos ressaltamos a importância da constituição de um discurso evangelizador por parte da inteligência cristã capaz de amalgamar as tradições romano-helenísticas e a mensagem do cristianismo, principalmente no processo de conversão da aristocracia de Roma, um grupo que se orgulha desta herança cultural.

Neste trabalho, nossa análise desta problemática, isto é, da conversão da aristocracia de Roma, e por conseguinte da sociedade tardo antiga, se deterá sobre a cristianização dos valores e virtudes romanas.

Em outras palavras os autores cristãos no intuito de converterem a aristocracia de Roma apropriaram-se das tradicionais virtudes romanas e deram a elas um novo conteúdo, um conteúdo cristão. Isto é, uniram a tradição romano-helenística com a doutrina cristã.

O nosso suporte documental para tal estudo serão as Cartas de São Jerônimo. A escolha por esta documentação não reside somente no fato de este autor ter realizado seus estudos em Roma, e por conseguinte ter uma formação intelectual nos moldes e parâmetros da herança cultural romano-helenistica, portanto sendo capaz de realizar a fusão desta tradição com a mensagem cristã. ${ }^{8}$

Jerônimo também conviveu, durante sua estadia em Roma como secretário do bispo de Roma, com a mais alta aristocracia desta cidade, representada pelo Círculo do Aventino. ${ }^{9}$

No entanto a importância de Jerônimo encontra-se fundamentalmente no fato de sua correspondência estar em grande parte dirigida a membros dạ aristocracia de Roma e estas epístolas possuírem o objetivo de despertar, incentivar e manter a fé cristã junto a este grupo social.

6 PASCOUD, F. Roma AEtema. Études sur le patriotisme romain dans l'Occident latin a l'époque des grandes invasions. Neuchâtel: Institut Suisse de Rome, 1967. p. 71-72.

7 SIMMACHI. Ep. I, 52. Monumenta Germaniae Historica. Auctores Antiquissimi. Berlin: [s.n.], 1883. vol VI.

8 PENAA BERCEDO, J. Actuación de San Jerónimo en la conciliación de las culturas paganes y cristiana. Burgos: Seminario Metropolitano de Burgos, 1957.

9 VIZMANOS, F. Las virgenes cristianas de la Iglesia primitiva. Madrid: BAC, 1949. p. 535. SERRATO, M. Ascetismo feminino en Roma. Estudios sobre San Jerónimo y San Agustín. Cadiz: Universidad de Cadiz, 1993. p. 89-100. 
Devido a,esses motivos, portanto, o epistolário jeronimiano constitui-se como uma fonte privilegiada para o estudo do processo de cristianização da aristocracia de Roma.

Para a compreensão e análise desta problemática, como afirmamos acima, é preciso reportarmo-nos às transformações ocorridas no mundo romano que marcam o início da Antigüidade Tardia, especialmente as mudanças nas estruturas religiosas e mentais.

O ponto de ruptura que marca o início dessas transformações é sem lugar a dúvidas a chamada "crise do III século". ${ }^{10}$

\section{1 - 0 "shock" mental da crise do III século}

O Império Romano atravessou duranite o III século um período particularmente difícil, marcado por inúmeros e diversos problemas, entre os quais podemos destacar: dificuldades monetárias, inflação, usurpações, guerras civis e constante pressão de povos hostis junto ao limes. ${ }^{11}$

Franz Maier afirma que: "Esta situación de crisis debió produzir um shock en la mentalidad de extensas zonas de la población imperial" ${ }^{12}$ Este choque ainda segundo o autor deve-se principalmente aos problemas nas fronteiras, pois a partir de então os romanos lutam dramaticamente por sua sobrevivência, entendida não somente como a manutenção material das fronteiras imperiais, mas também como preservação da tradição romano-helenística diante de outras culturas como a germânica ou a persa. ${ }^{13}$

$\mathrm{Na}$ verdade as dificuldades enfrentadas nas fronteiras apenas aceleram um conjunto de problemas internos vividos pela sociedade tardo romana. A crise mostra as contradições existentes na estrutura social imperial: a diferenciação entre o mundo mediterrâneo e o mundo das fronteiras, a hegemonia cultural e política da aristocracia romana que somente poderia ser mantida com um regime de paz algo quase impossível num momento, como a Antigüidade, marcado pela guerra em estado endêmico. ${ }^{14}$

Em suma, a Pax Romana tornou-se insustentável, as estruturas políticas, sociais, ideológicas, religiosas e mentais que haviam marcado os primeiros séculos do Império desde a época de Augusto não são mais capazes de fornecer as respostas às necessidades do homem romano.

10 A bibliografia acerca da crise do III século é muito extensa, e como nosso intuito não é discutir a crise em si, mas tomá-la como o ponto de partida para as transformações que marcam o início da constítuição de novas estruturas, principalmente religiosas que caracterizarão a Antigüidade Tardia, remetemos apenas para a síntese de RÉMONDON, R. La crisis del Imperio Romano. De Marco Aurélio a Anastasio. $4^{\mathrm{a}}$ ed. Barcelona: Labor, 1984, que apresenta uma vasta bibliografia acerca da problemática, assim como o debate acerca das principais tendências de análise da questão, seguindo o espirito e a tradição da coleção Nouvelle Clio, da qual esta obra faz parte.

11. ALFORDY, G. "The crisis of the third century as seen by contemporaries". IN Greek, Roman and Byzantine Studies. n 15; 1974. p. 89-111. PETTT, P. La crise de l'Empire. Paris: Flamarion, 1974.

12 MAIER, F. G. Op. cit. p. 20.

13 Idem. Op. cit. p. 19-22.

14 BROWN, P. Op. cit., p. 65-111. 
Nesta crise o aspecto religioso assume uma importância fundamental, para Peter Brown nada demonstra melhor o irrefutável fato de que a vida nos moldes e critérios clássicos havia se tornado intolerável, em decorrência dos problemas enfrentados pela sociedade imperial ao longo do II século, do que o desenvolvimento $e$ consolidação no seio desta estrutura social de um conjunto de crenças diverso da religiosidade clássica. ${ }^{15}$

Como afirma Dodds o mundo romano passa por um período de insegurança, uma época de angústia, na qual os problemas de ordem material acentuaram o ritmo das transformações religiosas. Ocorre então uma redistribuição, um reordenamento de elementos religiosos presentes há muitos séculos na bacia do mar Mediterrâneo. ${ }^{16}$

Esta reorganização da religiosidade tornará algumas crenças, até então restritas a certos grupos ou regiões, em elementos hegemônicos e constitutivos de uma nova sensibilidade religiosa que caracterizará a Antigüidade Tardia.

\title{
2- A nova religiosidade tardo romana
}

O primeiro elemento a ser ressaltado acerca da religiosidade tardo romana é o papel desempenhado pelos problemas religiosos; a partir de então as questões referentes à religião assumem um lugar de destaque na vida dos homens da Antigüidade Tardia, como demonstra esta passagem de Gregório de Nissa, acerca de Constantinopla:

\begin{abstract}
"A cidade está cheia de gente, que dizem coisas ininteligiveis e incompreensiveis pelas ruas, mercados, praças e cruzamentos. Quando vou à tenda e pergunto quanto tenho que pagar, me respondem com um discurso sobre o Filho engendrado ou não do Pai. Quando pergunto numa padaria pelo preço do pão, me responde o padeiro que, sem lugar a dúvidas, o Pai é maior que o Filho. Quando pergunto nas termas se posso tomar um banho, tenta demonstrar-me o banhador que com toda a certeza o Filho surgiu do nada". ${ }^{17}$
\end{abstract}

Seria, no entanto, errôneo pensar que esta preocupação com as questões religiosas fosse exclusiva dos cristãos, os pagãos compartilhavam das mesmas preocupações, pois o ambiente religioso era idêntico para ambos os grupos, como afirma Henri Marrou: "...la diferencia entre paganos y cristianos de la Antiguedad Tardia estaba en la verdad de sus respectivas elecciones, pero hay coincidencias en la atitud ante la concepción general de la vida, del hombre y del mundo". ${ }^{18}$

Outro elemento constitutivo da religiosidade tardo romana é o crescimento da crença no sobrenatural, isto é, para os homens deste momento o mundo invisível era uma realidade tão concreta quanto o mundo visivel. ${ }^{19}$

A sociedade tardo antiga era permeada pela crença de que o universo era partilhado com seres invisíveis, mais poderosos do que os homens, e com os quais tinha que manter relações, que eram encaradas uma obrigação inevitável. Como de-

15 Idem. Op. cit., p. 12.

16 DODDS, E. R. Paganos y cristianos en una época de angustia. Madrid: Cristiandad, 1975. p. 31.

17 GREGORIO DE NISSA. apud MAIER, F. G. Op. cit., p. 45-46̂.

18 MARROU, H. I. Op. cit., p. 45.

19 BROWN, P. Op. cit., p. 36. 
monstra o testamento de uma cristã egípcia que distribuiu seus bens entre beneficiários visíveis e invisíveis, acreditando estar cumprindo o seu dever de ser humano. ${ }^{20}$

A importância atribuída aos demônios neste momento é um fator revelador do destacado papel desempenhado pelo sobrenatural na religiosidade tardo romana. Os demônios deixam de ser os intermediários entre o mundo celeste e o mundo terreno, para tornarem-se a fonte preferencial e ativa das ilusões humanas, como afirma Peter Brown: "Daqui a revelação crucial destes dois séculos (III e IV século) - o aparecimento definitivo dos demônios, forças ativas do mal, contra os quais os homens teriam que lutar". ${ }^{21}$

A vida do homem torna-se um campo de batalha entre as forças invisiveis, o pecado já não é só errar, mas também se deixar levar pelas forças do mal. O cristianismo e a Igreja são os grandes promotores e beneficiários desta concepção acerca dos demônios, pois fora do âmbito cristão, os demônios são definidos como espíritos ambivalentes. ${ }^{22}$

O papel desempenhado pelos demônios no imaginário da sociedade tardo antiga demonstra os dois elementos analisados da nova religiosidade da Antigüidade Tardia: por um lado a importância da questão religiosa, por outro a crença na presença marcante e decisiva do sobrenatural na vida dos homens.

O terceiro elemento constitutivo da religiosidade tardo romana é a concepção acerca da divindade que se torna hegemônica. ${ }^{23}$ A partir de então Deus passa a ser entendido como sendo único, absoluto, eterno, onipresente, porém, principalmente é percebido como um Deus pessoal que inspira não somente adoração, mas também amor, porque Ele próprio possui amor e misericórdia pelos homens, ou seja é um philanthrôpos. ${ }^{24}$

Esta concepção acerca da divindade é essencialmente uma contribuição do pensamento semítico oriental, especialmente da teologia judaica, na qual o antecedente mais antigo do monoteísmo encontra-se na religião de Abraão, ${ }^{25}$ isto não sig-

20 WIPSZINCKA, E. Les ressources et les activités économiques des Églises en Égypte. Bruxelles: [s.n.], 1972.

21 BROWN, P. O fim do mundo antigo. De Marco Aurelio a Maomé. Lisboa: Verbo, 1972. p. 57.

22 A definiçăo platônica de demônio é o de intermediário entre a divindade e os homens, como podemos perceber nesta passagem: "O demoníaco é todo aquilo que media Deus e os mortais. Une ambos os extremos e enche o vazio que nos separa, interpretando e transmitindo os desejos dos homens aos deuses e a vontade dos deuses aos homens [...]. Deus não entra em contato com o homem, somente através do demoníaco pode ocorrer a comunicaçäo entre os homens e os deuses, seja em vigilia, seja em sonho" (Simp. , 202d; 13-203). Esta concepção é um lugar comum no século II d.C., pois pagăos, judeus, gnósticos e até mesimo cristãos acreditavam nestas entidades e em suas funções mediadoras.

23. ARNALDEZ, R. "Um só Deus". IN BRAUDEL, F. Os homens e a herança no Mediterrâneo. São Paulo: Martins Fontes, 1988. p. 1-25.

25 SCHMIDT, W. The origens of God's idea. London: [s.n.], 1912. Nesta obra o autor afirma a existência de um monotèismo primitivo anterior ao politeismo, que teria sido substituído pelo panteão pagão por ser pouco acessivel e menos atraente que a multiplicidade de deuses. A tese de Schmidt é polêmica e bastante discutida, de qualquer forma mesmo que a hipótese do autor seja confirmada e aceita as origens do monoteísmo durante a Antigüidade Tardia remete-se ao pensamento judaico $\varepsilon$ grego e não a este monoteísmo primordial. 
nifica porém, que a idéia de um único Deus tenha se desenvolvido numa linha reta de evolução lógica, mas sim através de uma trilha acidentada, onde o contexto histórico, as pressões sócio-econômicas e ideológicas desempenharam um papel fundamental. ${ }^{26}$

Não devemos esquecer, no entanto, a aportação que a filosofia grega e helenística faz ao desenvolvimento da idéia monoteísta, através do conceito de Bem platônico ou do Motor Primeiro de Aristóteles, mas principalmente por intermédio das concepções neoplatônicas de Proclus, Jamblico ou Porfírio, ${ }^{27}$ assim como a contribuição das religiões de mistérios orientais. ${ }^{28}$

Certamente que em meios pagãos tradicionais o politeísmo continua a existir, mas apresenta um caráter arcaico e encontra-se sem apoio, ${ }^{29}$ e mesmo nestes focos de resistência o monoteísmo influi através de um duplo esforço de interpretação:

- assimilação: ou seja, a identificação por equivalência, na qual sob diversas denominações um mesmo Deus está em todas as partes.

- hierarquização: estabelece-se entre as distintas divindades uma ordenação hierárquica que as subordina ao Deus supremo. ${ }^{30}$

Em suma, a concepção de um Deus único não era uma exclusividade judaicocristã, encontrava-se espalhada por todas as tendências religiosas existentes na Antigüidade Tardia, evidentemente com matizes diferenciados entre os diversos grupos e doutrinas.

O último aspecto a ser destacado da religiosidade tardo romana é a importância crescente que adquirem as questões ligadas à salvação e à vida após a morte. ${ }^{31}$

A preocupação dos homens volta-se para esta outra vida, que é entendida como sendo feliz e bem-aventurada, desde que se consiga obtê-la através da salvação. É significativo que a palavra latina salus que designa para os romanos antigos a saúde física, passe a ser utilizada pelos autores cristãos para denominar a salvação eterna. ${ }^{32} \mathrm{O}$ que constitui um exemplo deste processo que estamos analisando de fusão entre a tradição romano-helinística e a doutrina cristã.

A breuis lux da qual nos fala Catulo é substituída pela lux perpetua como 0 aspecto mais real e mais importante da existência humana; por isso, o lugar central que a questão da salvação assume para os homens do mundo tardo antigo romano.

Após analisar os principais elementos constitutivos da nova religiosidade tardo romana, uma questão pode ser levantada: os aspecțos abordados não sã́o novos, encontram-se presentes no universo religioso clássico. A esta objeção as palavras de Frederic Jameson representam a melhor resposta:

"Devo limitar-me à sugestão de que as rupturas radicais entre periodos geralmente năo envolvem mudanças completas de conteúdo, mas, antes, a reestruturação de um certo número

26 BAGU, S. La idea de Dios en las sociedades de los hombres. México: Siglo XXI, 1989. p. 85.

27 ARNALDEZ, R. Op. cit., p. 4.

28 ANGUS, S. The mystery religions and christianity. New York: Ithaca, 1925. p. 58.

29 MARROU, H. I. Op. cit., p. 50.

30 Idem. Op. cit., p. 50-51.

31 Idem. Op. cit., p. 51.

32 Idem, ibidem. 
de elementos já dados: traços subordinados tornam-se dominantes, e traços que tinham sido dominantes, por sua vez, tomam-se secundários". ${ }^{33}$

É incontestável, no entanto, que a principal manifestação da religiosidade tardo romana é o triunfo do cristianismo que ao longo do IV século torna-se a religião hegemônica da sociedade baixo imperial tanto numérica quanto culturalmente, ${ }^{34} \cdot \mathrm{a}$ ponto de constituir-se na religião oficial do Império sob a égide do imperador Teodósio. ${ }^{35}$

\section{3 - O triunfo do cristianismo}

No começo do IV século, o cristianismo aparece diante do Estado romano como mais uma das diversas religiōes de mistério que possuiam suas origens no Oriente e que se espalham, neste momento, por todo o Império. ${ }^{36}$

A situação começa a modificar-se com as medidas de tolerância adotadas pelos imperadores Licínio e Constantino, no ano de 313 , que a Historiografia denomina de Édito de Milão. ${ }^{37}$ A partir de então, o cristianismo torna-se uma religio licita, equiparando-se às demais religiões existentes no Império.

Mais importante, porém, que a tolerância e a liberdade de culto, para o triunfo do cristianismo, foi o apoio estatal após a conversão do imperador Constantino, ${ }^{38}$ que passa a favorecer decididamente a Igreja cristã.

É importante destacar que o favorecimento estatal é sem sombra de dúvidas um elemento importante para a compreensão no triunfo do cristianismo, mas que por si só não explica este fenômeno. É preciso considerar outros aspectos na análise de tão complexa problemática.

Um dos aspectos mais importantes para o triunfo do cristianismo são os fatores internos da Igreja, que neste momento reunia condições para usufruir deste favorecimento estatal, em outras palavras, possuia uma estrutura hierárquica eficaz e desenvolvida, uma grande coesão interna e também um grupo de pensadores capazes de transmitir a mensagem cristã tanto à elite romana quanto ao restante da população, isto é, uma inteligência capaz de construir diversos e diferentes discursos evangelizadores adequados aos vários grupos sociais que compunham a sociedade tardo antiga romana.

No entanto o fator que consideramos primordial no processo de triunfo do cristianismo é que este consegue atender às necessidades espirituais do homem tardo

33 JAMESON, F. "O pós-modemismo e a sociedade de consumo". IN ANN KAPLAN, E. (org). O mal-estar no pós-modernismo. Teorias e práticas. Rio de Janeiro: Zahar, 1993. p. 41.

MARROU, H. I. Op. cit., p. 46.

MAIER, F. G. Op. cit., p. 65.; MARROU, H. I. e DANIÉLOU, J. A nova história da Igreja. Petrópolis: Vozes, 1984. p. 314.

ANGUS, S. Op. cit., p. 102.; BURKERT, W. Antigos cultos de mistério. São Paulo: EDUSP, 1991. p. 99-123.

SIMON, M. e BENOIT, A. Judaísmo e cristianismo antigo. Sảo Paulo: EDUSP/Pioneira, 1987. p. 191.

Idem. Op. cit., p. 193. A polêmica acerca da conversão do imperador Constantino é muito extensa; por não ser a questão primordial deste estudo, apesar de importante, limitamo-nos a remetermos à obra citada que apresenta as principais perspectivas de análise da problemática, assim como uma alentada bibliografia. 
romano, isto é, diante das transtormações ocorridas no campo da religiosidade e do universo mental a religião cristã acaba por constituir-se como a principal expressão destas mudanças. Vejamos um exemplo.

Neste momento, ou seja, durante a Antigüidade Tardia, os homens do Mediterrâneo em número e entusiasmo crescente passaram a aceitar que o poder divino não se encontrava mais em indivíduos comuns através da revelação ou das instituições estabelecidas; a partir de então o poder divino estava representado na terra por um número restrito de agentes humanos especiais que haviam recebido o privilégio de comandar a ação do poder divino entre os homens, devido a sua ligação com o sobrenatural, relação claramente percebida e aceita pelos outros crentes. ${ }^{30}$

A organização e a capacidade cristã de criar, de produzir "heróis" torna a Igreja a grande beneficiária desta focalização do poder divino. Åo longo da Antigüidade Tardia a hierarquia eclesiástica e os santos cristãos tornaram-se o elo, por excelência, de ligação entre o mundo celeste e o mundo terreno. ${ }^{40}$

As hagiografias que marcam e caracterizam a literatura da Antigüidade Tardia centraliza numa única pessoa o poder divino que na religiosidade clássica encontrava-se difuso por todo o grupo de crentes, estes escolhidos estão separados da sociedade e num estado superior em decorrência de sua proximidade com o sobrenatural. ${ }^{41}$

É diante deste quadro que o processo de triunfo do cristianismo deve ser analisado, ou seja, no seio de um universo mental e religioso, no qual os homens aceitam investir poderes quase ilimitados em certos membros da sociedade em decorrência da ligação mais estreita que este grupo mantém com o sobrenatural, com o divino.

Em suma, a vitória da religião cristã deve ser abordada dentro do processo de consolidação e hegemonia de uma nova religiosidade, isto é, como a manifestação do estabelecimento de uma nova relação dos homens com o sagrado que caracteriza a Antigüidade Tardia.

Por outro lado a ascensão do cristianismo não pode ser analisada separadamente das profundas transformações que estão ocorrendo na sociedade tardo antiga. Na medida em que o triunfo da religião cristã.não é um processo gradual e irresistível que se inicia com os apóstolos, mas um fenômeno inesperado no mundo romano. $^{42}$

O cristianismo torna-se a partir do III século um elemento importante nas cidades, demonstrando que supria uma necessidade da sociedade tardo antiga. Num momento de desamparo, as comunidades cristãs são as únicas a prestar alguma solidariedade e assistência aos que precisam. Neste período ser cristão assegura mais garantias do que ser cives romanus. ${ }^{43}$

BROWN, P. Genese... p. 39.

BROWN, P. Op. cit., p. 40.

BROWN, P. Op. cit., p. 43.

BROWN, P. O fim do mundo clássico... p. 68.

BROWN, P. Op. cit., p. 72. 
Em realidade o que constatamos a partir do IV século é que as religiões pagãs vivenciam um processo de progressivo debilitamento, apesar de não terem sofrido, pelo menos até Teódosio, nenhuma medida restritiva aos seus cultos. O paganismo acaba limitando-se a um pequeno círculo aristocrático ligado às antigas tradições Iomanas, ${ }^{44}$ ou a zonas rurais menos desenvolvidas e romanizadas. ${ }^{45}$

Por seu turno o cristianismo inicia um período de franca expansão tanto dentro das fronteiras imperiais, passando a conquistar adeptos em todos os grupos da sociedade tardo antiga, quanto fora dos limites do mundo romano; assiste-se então à cristianização de regiões como a Armênia, a Etiópia ou mesmo de alguns povos da Germânia. $^{46}$

Franz Maier define desta maneira o processo de triunfo do cristianismo:

"Los decenios que van desde Constantino a la muerte de San Agustin ( 430), constituyeron la gran epoca de la cristiandad. De una secta, no sin influencia pero si reduzida, la Iglesia se convertió con gran rapidez en una organización que abarca todo el Império". 47

Em suma podemos afirmar que ao longo do IV século o cristianismo torna-se uma religião triunfante, cujos adeptos têm consciência de pertencer a uma comunidade que havia conquistado a liberdade e para qual abre-se um largo horizonte de perspectivas.

Um desses homens é sem dúvida São Jerônimo que personifica o novo homem que marca a sociedade tardo antiga, isto é, um homem que mantém todo o legado cultural e os valores romanos, mas que também é um cristão. Alguém que consegue fundir essas duas tradições criando algo original, ou seja, a civilização romano-cristã, a civilização da Antigüidade Tardia.

Passemos então a analisar um exemplo concreto deste processo de união entre a tradição romana e a doutrina cristã.

\section{4-A fides romana}

Os valores morais romanos e suas idéias políticas formam uma das partes mais significativas do legado cultural romano, a ponto de podermos afirmar que o mundo moderno, consciente ou inconscientemente, define seus parâmetros de comportamento segundo a adesão ou rejeição a estes ideais. . $^{4}$

A fides é um dos principais valores morais e políticos romanos, segundo Pierre Boyancé. Se perguntássemos a um romano o elemento distintivo de seu caráter e 0 fator que levou Roma a dominar o mundo mediterrâneo, a resposta não seria nem o valor militar, nem a coragem dos soldados e nem o gênio dos chefes militares, mas

44 LABRTOLLE, P. Op. cit., p. 124 .

45 MOMIGLIANO, A. El conflicto entre el paganismo y el cristianismo en el siglo IV. Madrid: Alianza, 1989. p. 41.

46 MARROU, H. I. e DANIÉLOU, J. Op. cit., p. 290-305.

47 MAIER, F. G. Op. cit., p. 45.

48 PEREIRA, M. H. R. Estudos de história da cultura clássica. Lisboa: Calouste Gulbenkian, 1989. p. 321. 
o respeito dos romanos pelos deuses, isto é, a pietas. Como afirma Horácio: "... tu te conduis en inférieur des dieux que tu comandes". ${ }^{49} \mathrm{O}$ herói de Virgílio é o Pius - Áneas em oposição a Aquiles ou a Ulisses dos gregos. O poder dos romanos é entendido como uma recompensa pela pietas romana. ${ }^{50}$

No entanto, se perguntarmos aos romanos o que permite que Roma se imponha em relação aos outros homens a resposta será que isto ocorre devido a fides . Entendida como uma disposição permanente de vontade, como a fidelidade às obrigações e especialmente aos compromissos, como a integração, a concordância entre as palavras e os atos, principalmente quando estes são anunciados anteriormente; nestes casos o compromisso ganha uma força superior devido à garantia dos deuses conseguida através do juramento. A fides, portanto, não é uma noção exclusivamente laica, ela é perpassada pelo divino. ${ }^{51}$

Desta forma concordamos com Pöschl que afirma que a fides encontra-se no centro da estrutura política, social, jurídica e moral romana, ${ }^{52}$ sendo portanto uma virtude de grande importância no imaginário da aristocracia de Roma e que necessariamente os pensadores cristãos, especialmente São Jerônimo, deveriam cristianizar no processo de construção de um discurso evangelizador para a conversão deste grupo social.

O histórico do termo foi feito por Eduard Fraenkel; segundo o autor o sentido habitual de fides como "confiança", dado pelos léxicos não é anterior a Cícero, e que o significado usual na literatura republicana é de "garantia", sendo este o seu valor originário. ${ }^{53}$

O Eduard Fraenkel afirma ainda que o sentido da fides enquanto "crença" não é cristão, mas já aparece em Cícero, na obra Da invenção e na Retórica a Herénio. ${ }^{54}$

A etimologia moderna da palavra explica que o termo fides vem da raiz bheidh que significa persuadir, de onde "deixar-se persuadir" e "confiar" ${ }^{55}$ Neste particular a relação estabelecida por Varrão da fides com foedus e fit nos mostra melhor a ligação da virtude como as relaçöes entre os homens, que se constituiu na essência do conceito de fides. ${ }^{56}$

Cícero em A República afirma o seguinte acerca da fides: "[...] pois a fides parece-me tirar o próprio nome do fato de se fazer o que se diz"..$^{57}$ Em outras palavras a fides deve ser entendida como o juramento em que duas partes se comprometem à observância de um pacto bem firme. ${ }^{58}$

49 HORÁCIO apud BOYANCÉ, P. Études sur la religion romaine. Paris: École Française de Rome, 1972. p. 135.

50 BOYANCÉ, P. Op. cit., p. 135.

51 Idem, ibidem.

52 PÖSCHL, V. "Politische Wertbegriffe in Rom". p. 1-17 IN Antike und Abendland. $n^{2} 25,1980$. p. 3.

53 FRAENKEL, E. "Zur Gerschichte des wortes Fides". IN Rhenisches Museum. n² 71, 1916. p. 187-199.

64 Idem, ibidem.

55 PEREIRA, M. H. R. Op. cit., p. 323.

56 VARRÃO. Da língua latina. V. 86.

57 CICERO. A República. IV. 7,7.

58 PEREIRA, M. H. R. Op. cit., p. 324. 
Uma das melhores fontes para o estudo da fides, paradoxalmente não é um romano, mas um grego: Polibio. $O$ historiador helênico reconhece o valor da fides no universo moral romano, afirma ele: "[...] respeita o seu dever, pela própria fidelidade. decorrente do seu juramento". 50

Polibio, ao comparar a história dos gregos na época helenistica com a história dos romanos, não hesita em exaltar a fides romana em detrimento da de seus compatriotas. Políbio também reconhece a superioridade moral do povo de Roma, a que atribui a sua constituição e ao respeito aos deuses, pois para ele a pietas é a base da fides. ${ }^{\infty}$

Não é apenas em Políbio que podemos perceber a importância da fides para os romanos. Na obra de Tito Lívio também observamos o papel destacado desempenhado por esta virtude que, para o autor, é a qualidade distintiva do povo romano em relação aos cartagineses e aos gregos. ${ }^{61}$

Outro aspecto fulcral a ser destacado acerca da fides é que a divindade que leva o nome desta virtude é cultuada em Roma desde os primórdios de sua história. O seu culto assume tal importância que seu templo serve como arquivo da República romana e muitas vezes o Senado reuniu-se em seu recinto. ${ }^{6}$

A origem do culto a fides é uma problemática muito discutida e que ainda não se chegou a um consenso. Para Pierre Boyancé, utilizando Varrão como fonte, afirma que é plausivel que o culto seja uma aportação advinda dos sabinos, pois existe documentação que atesta o culto da fides entre povos itálicos, como os ombrianos, vizinhos dos sabinos. ${ }^{63}$

- Por outro lado, George Dumezil afirma que o culto da fides é pré-romano e com paralelos na Índia devido a uma origem comum indo-européia. ${ }^{64}$ Deixemos, porém, as especulações historiográficas e passemos a tentar compreender a função desta virtude na sociedade romana.

Para Maria Helena da Rocha Pereira encontra-se na fides um elemento para explicar a espantosa capacidade romana de congregar diversos povos sob seu comando, ${ }^{65}$ pois como afirma Cícero:

"[...] o Senado era o porto de abrigo de reis, povos e nações, e nossos magistrados e generais ansiavam por obter um único título de glória, o de terem defendido as províncias e os aliados com justiça e fides. ${ }^{6}$

A fides é um dos conceitos básicos sobre o qual a sociedade romana está assentada, uma das virtudes sobre a qual a moral dos romanos se constrói. A fides perpassa todos os âmbitos da vida dos homens de Roma, desde o direito privado

5 POLfBIO. apud PEREIRA, M. H. R. Op. cit., p. 324.

$\infty$ BOYANCE, P. Op. cit., p. 136-137.

61 Idem, Op. cit., p. 138.

62 PEREIRA, M. H. R. Op. cit., p. 235.

๓ BOYANCE, P. Op. cit., p. 141. O texto de Varrão sobre o qual o autor se apoia é Da língua latina. V. 74.

64 DUMEZII, G. Idées romaines. Paris: Gallimard, 1969. p. 47-59.

क5 PEREIRA, M. H. R. Op. cit., p. 325.

66 CICERO. Dos deveres. II. 8,26. 
até $\mathrm{o}$ direito internacional, desde $\mathrm{o}$ aspecto religioso chegando até a politica e a administração, pois acreditava-se que as províncias estavam unidas pela potestas e pela fides, isto é, esta última era o cimento do Império, além de ser a característica distintiva do modo romano de estar no mundo. ${ }^{67}$

Em suma, na época clássica romana não existe nada mais nobre que as idéias que se encontram interligadas com a fides: lealdade, fidelidade aos compromissos, firmeza de caráter. ${ }^{68}$

\section{5 - A fides cristã}

Após analisarmos o conceito de fides na tradição romana é necessánio nos determos na abordagem desta virtude na tradição judaico-cristã, pois é da síntese, da confluência destas duas tradições que São Jerônimo construirá a idéia de ưma fé romana e cristã, no bojo de um discurso que tem por objetivo a cristianização da aristocracia de Roma.

$\mathrm{O}$ conceito de fé $\dot{e}^{69}$ possui no seio da tradição judaico-cristã importância fundamental, podemos afirmar mesmo que é o sustentáculo, o ponto nodal desta cultura.

No Antigo Testamento a raiz hebraica mais usada para expressar a fé de Israel em Deus é ' $m n$, que indica estabilidade, firmeza, convicção, respeitabilidade, credibilidade. Desta raiz deriva tanto o verbo 'aman que expressa a idéia de firmeza, donde por derivação verdade, ${ }^{70}$ quanto as palavras 'emunah e 'emet que significam fidelidade. ${ }^{71}$ Etimologicamente, portanto, o conteúdo do termo fé encontra-se ligado a idéias como lealdade, constância e cumprimento das promessas.

Acerca do conceito de fé no Antigo Testamento podemos afirmar que este possuía uma caráter ontológico, isto é, de definição do ser ou não ser. Em outras palavras o ser hebreu era algo definido pela fé no Deus de Israel.

Quanto ao Novo Testamento, a fé assume um papel destacado, ocupando mesmo a posição central na doutrina neotestamentária. ${ }^{72}$ Em Marcos a predicação de Jesus está intimamente relacionada com a fé: "Depois que João foi preso, veio Jesus para a Galiléia proclamando o Evangelho de Deus: "Cumpriu-se o tempo e o Reino de Deus está próximo. Arrependei-vos e crede no Evangelho".73

Em Paulo a fé encontra-se relacionada com a história da Igreja, o kerigma apostólico dișpõe os ouvintes à fé, à conversão, à volta para Deus: "Porque, se confessares com tua boca que Jesus é o Senhor e creres em teu coração que Deus o ressuscitou dos mortos, serás salvo". ${ }^{74}$

67 PEREIRA, M. H. R. Op. cit., p. 328.

6 BOYANCÉ, P. Op. cit., p. 142.

๗ Utilizaremos o termo fé para designar este conceito dentro do cristianismo e para diferenciá-lo da virtude romana da fides.

Ver Is 7,9: "si não creeis(ta'amenu), não tereis estabilidade(te'amenu).

71 BERNARDINO, A. (org). Diccionario Patrístico y de la Antigüedad cristiana. Salamanca: Sigueme, 1991. 861. vol. I.

72 Idem, ibidem.

73 Mc 1, 14-15.

74 Rom 10,9. 
A teologia grega dos três primeiros séculos elabora um novo conteúdo para o conceito de fé, isto é, entende esta virtude como conhecimento; na Epistola de Barnabé os cristãos possuem a sabedoria juntamente com a sua fé, e principalmente devido a ela, "[...] o conhecimento verdadeiro", gência, a ciência e o conhecimento". ${ }^{76}$

Evidentemente que este conceito de fé como conhecimento construído pela teologia grega é fruto do contato do cristianismo com a tradição cultural helenística, ọ seja, no momento em que a doutrina cristã se encontra com a filosofia helênica procura adaptar-se a esta nova influência e neste processo acaba transformando-se, como também provoca mudanças no seu seio do pensamento grego. ${ }^{n}$

Este processo é importante não somente pelas repercussões observadas tanto dentro do cristianismo quanto no seio do pensamento grego, mas também por iniciar o fecundo diálogo entre a doutrina cristã e tradição clássica. Nosso estudo analisa um momento deste encontro, onde mais uma vez essas duas culturas estão interagindo uma sobre a outra, para criar algo novo e original, isto é, a cultura romano-cristã,

A construção desta cultura se nos apresenta como um elemento fundamentāl para a compreensão e análise da conversão da aristocracia de Roma, pois permitiu que através de um discurso que mantém e preserva os parâmetros e os moldes advindos da tradição cultural romano-helenística a mensagem cristã atingisse este grupo. É o que observamos na construção do conceito de fé/fides realizado por São Jerônimo. A análise desse conceito será realizado tomando como base documental o epistolário jeronimiano, ${ }^{78}$ em especial as cartas dirigidas à aristocracia de Roma.

O primeiro elemento a ser destacado no conceito de fé/fides jeronimiano é que "este valor é o elemento que diferencia o homem dos outros animais e por conseguinte é o fator que carateriza a humanidade", afirma o autor, numa epistola dirigida ao Círculo do Aventino, um grupo de nobres romanas, quando da morte de Paula, uma das integrantes deste cenáculo:

"Pero oh quebradiza y caduca naturaleza de los mortales! Si la fe de Cristo no nos levanta hasta el cielo y no se nos prometiera la eternidad del alma, nuestra condición seria la misma que de los animales y bestias de carga".79

Por esta passagem do epistolário jeronimiano é possivel perceber que para o nosso autor a condição de humanidade é definida pela fé/fides, ou mais especificamente pela fé cristã. Isto, porém, não significa que a romanidade tenha sido aban-

75

76

77 A problemática da relação, do diälogo entre o cristianismo e a filosofia grega foi abundamente discutida; limitamos a citar a obra de JAFGER,W. Cristianismo Primitivo y paideia griega. México: Fondo de Cultura Económica, 1961, pelas inquietantes e importantes questões colacadas; SÁNCHEZ SALOR, E. Polémica entre cristianos y paganos. Madrid: Akal, 1986, por abordar a questão através de uma vasta análise da documentação existente. Assim como a obra de COCHRANE, C.N. Cristianismo y cultura clásica. México: Fondo de Cultura Económica, por ser um clássico sobre o tema.

78

79 ção, versão e notas de DANIEL RUIZ BUENO. Madrid: BAC, 1962. 2 v. 
donada como ideal de homem; na verdade como um romano-cristão, São Jerônimo concebe a fë/fides inerente e presente no mundo romano, o que está além do limes imperial pouco interessa, ou seja, o conceito de fé/fides apresenta-se assim como uma releitura da idéia de romanidade como definidora do humano.

Um segundo elemento do conceito que estamos analisando no pensamento de São Jerônimo, que se liga ao primeiro e se reveste de especial importância na construção de um discurso evangelizador para a aristocracia de Roma, encontramos na seguinte passagem da carta $\mathrm{n}^{2} \mathrm{LXV}$, dirigida a Princípia, uma nobre romana que decidiu consagrar a sua castidade e que tanto se integra ao Círculo do Aventino:

"Pero cabe perguntar cómo la Iglesia venida de la gentilidad pueda tener por padres a Abrahán, Isaac y Jacob... Y es asi que, como él fue justificado en el prepucio por la fe, así también nosotros somos justificados por la misma fe, caso tengamos la fe y las obras de nuestro padre Abrahán. Esto mismo puede ser dicho al Salvador, ora por el Padre, ora por el coro profético y el Espíritu Santo: 'En lugar de tus padres, es decir, la casta de los judios que te abandonaron y negaron, țe han nascido hijos: los apóstoles y los creyentes de las naciones a los que has constituido príncipes sobre la tierra". 80

Neste trecho de seu epistolário São Jerônimo em primeiro lugar justifiça a apropriação por parte do cristianismo da herança vetero-testamentária, pois para ele existe um elemento que perpassa esta tradição e também a doutrina cristã, a fé/fides em Deus. Portanto, o legado do Antigo Testamento não é dos hebreus, mas sim de todos aqueles que possuem a fé/fides em Deus.

Em outras palavras, o que define e caracteriza o cristão é a fé/fides, este valor, esta virtude concentra o modo de ser cristão, ou seja, São Jerônimo apropria-se aqui de elementos da fides romana que, como vimos, é um conceito que elabora e molda o ser romano.

A fé/fides jeronimiana estabelece, assim como a fides romana, um pacto, um compromisso, mas não mais entre dois homens e sim entre os homens e Deus, em outros termos São Jerônimo espiritualiza a fides romana, faz esta ligação transcender os limites do mundo terreno, mas mantém esta virtude como sendo o elemento definidor do modo de ser cristão, assim como acontecia no imaginário tradicional romano; onde este valor caracterizava o ser romano.

Um terceiro elemento compõe o conceito jeronimiano de fé/fides: a aceitação da religião cristã confere aos homens uma dignidade, isto é, a conversão à fé cristã introduz o homem numa comunidade em que o critério de distinção năo é a antigüidade da fé, mas esta em si mesma. Vejamos este trecho da carta dirigida a Paulino, nobre romano:

"No me estimes, pues, hermano carissimo, por el número de años, ní calcules la sabiduría por las canas, sino las canas por la sabiduria, como testifica Salomón: 'Las canas del hombre son su inteligencia' (Sb 4,9). Asi vemos que a Moisés se le manda escoger setenta ancianos; que supiera él eran ancianos y a fe que no les había de juzgar por la edad, sino por la prudencia; y Daniel, muchacho aún, juzga a los de avanzada edad, y la edad que pasa por lasciva condena a los viejos impúdicos. No peses, digo, la fe por los años, ni me tengas por mejor por el mero hecho de haber sentado antes plaza en el ejército de Cristo" ${ }^{81}$

80 Ep. LXV, 21.

81 Ep. LVIII, 1. 
Este elemento do conceito jeronimiano de fé/fides reveste de especial importância na construção do discurso de conversão da aristocracia de Roma: na medida que um grupo que considera a si mesmo como a melhor e mais alta expressão do gênero humano não admitiria ser considerado como tendo uma dignidade menor, por ter abraçado a religiảo cristã posteriormente a outros grupos inferiores na estrutura social baixo imperial.

Diante desta problemática o conceito de fé/fides de São Jerônimo resolve a questão de modo muito claro e favorável à aristocracia de Roma, isto é, não é a antigüidade que confere dignidade ao cristão, mas sim a sua vivência na fé. Isto permite que os nobres romanos ao se converterem à religião cristã mantenham intacto o seu prestígio social e moral, que lhes garante a hegemonia nesta sociedade.

0 último elemento acerca do conceito de fé/fides jeronimiano a ser abordado encontra-se explicitado na epístola de $n^{2} 120$, destinada à viúva cristã Hedibia. ${ }^{82}$ Vejamos a seguinte passagem:

"Pero como los hombres están dejados a su libre albedrio, ya que no hacen el bien forzosa, sino voluntariamente, de modo que los creyentes reciben la corona y los incrédulos sean destinados a los suplicios, de ahi que nuestro olor, que de suyo es bueno, por la virtud o el vicio de quienes o el vicio de quienes lo reciben o no lo reciben, pasa a ser olor de vida o muerte: los que creen, se salvan; los que no creen, perecen". ${ }^{83}$

Podemos perceber através deste trecho do epistolário jeronimiano que, para o nosso autor, a fé/fides encontra-se intimamente relacionada com a salvação. Esta virtude torna-se a principal garantia da vida eterna, pois é capaz de garantir a salvação. $\mathrm{E}$ não devemos esquecer a importância desta temática no seio da religiosidade tardo romana antiga.

Em suma, São Jerônimo, ao construir um discurso evangelizador para a aristocracia de Roma, procurou atender às necessidades religiosas e espirituais deste grupo social, que são os mesmos expressos na religiosidade da Antigüidade Tardia.

Em outras palavras, o discurso cristianizador jeronimiano não apenas amalgama as tradições culturais romanas e cristãs, mas também atende aos anseios religiosos da aristocracia de Roma que estão inseridos no universo religioso tardo romano antigo.

\section{6 - Conclusão}

O conceito de fé/fides jeronimiano é de grande relevância para o estudo do fenômeno da cristianização da sociedade tardo romana. Em primeiro lugar, por esta

82 A identificação da destinatária na carta CXX é motivo de grandes discussões. Labourt afirma que Hedibia é uma mulher agradável, fina, inteligente, cristã fervorosa e muito curiosa acerca das coisas divinas. Ver SAINT JÉROME. Lettres. Texte établi et traduit par JERÓME LABOURT. Paris: Belles Lettres, 1949. vol. 6. p. 96 . O certo é que Jerônimo nāo a conhecia pessoalmente, pois inicia a carta dizendo: "Desconocida de cara, me eres conocidisima por el ardor de tu fe" (Ep. CXX, prefácio.). Para Ruiz Bueno, Hedibia era uma cristã fervorosa, viúva que viveu a passagem do IV para o V século. (ver JERONIMO. Op cit., vol II. p. 440-441). Em nosso entender existe uma grande possibilidade de Hedibia ter tido algum tipo de contato com o Circulo do Aventino através do qual teria acesso ao nosso autor. 
concepção coadunar-se plenamente com os elementos formativos da religiosidade da Antigüidade Tardia. Demonstrando, portanto, que o processo de conversão da estrutura social imperial é uma manifestação deste novo ambiente religioso.

Por outro lado, o conceito de fé/fides elaborado por São Jerônimo amalgama as duas grandes tradições culturais presentes na sociedade tardo romana, isto é, a herança romano-helenística e o cristianismo. Nosso autor mostra que é possível construir um discurso que realiza a fusão desses dois legados, ou seja, a constituição de uma cultura romano-cristã.

Finalmente é a construção desta cultura romano-cristã um dos elementos decisivos, ainda que não o único, para compreendermos o processo de cristianização da aristocracia de Roma, pois permite que este grupo se converta sem ter que abdicar de valores que constituiam o cerne de sua identidade. São Jerônimo mostrou à aristocracia de Roma que era possivel ser cristão sem deixar de ser romano. 